АНГЛІЙСЬКА МОВА ЗА ПРОФЕСІЙНИМ СПРЯМУВАННЯМ ЯК ВАЖЛИВА СКЛАДОВА ЧАСТИНА ПРОФЕСІЙНОГО СТАНОВЛЕННЯ СТУДЕНТІВ ТЕХНІЧНИХ СПЕЦІАЛЬНОСТЕЙ

\title{
PROFESSIONALLY-ORIENTED ENGLISH AS AN IMPORTANT COMPONENT OF PROFESSIONAL FORMATION OF STUDENTS OF ENGINEERING PROFESSION
}

УДК 378.147: 881.111

DOI https://doi.org/10.32843/26636085/2021/34-2.17

\section{Малик Т.В.}

студентка II курсу

Інституту іноземних мов

Дрогобицького державного

педагогічного університету

імені Івана Франка

\section{Грицик Г.О.,}

викладач іноземних мов

Дрогобицького механіко-технологічного фрахового коледжу

\section{Малик Л.Б.,}

канд. пед. наук,

викладач загальнотехнічних дисциплін Дрогобицького фрахового коледжу насрти і газу
У статті розглянуто особливості процесу вивчення англійської мови за просесійним спрямуванням студентами технічних спеціальностей, формування у них відповідних профресійних знань і вмінь у середовищі іншомовної комунікації.

Проаналізовано сутність понять «іноземна мова за професійним спрямуванням», «англійська мова за просресійним спрямуванням», «профресійне спрямування», «профресійна компетентність».

Розкрито основні вимоги сучасності щодо профресійного становлення студентів технічних спеціальностей і забезпечення процесу навчання англійської мови за професійним спрямуванням.

Зазначено, що поглиблене вивчення англійської мови за професійним спрямуванням відкриє можливості майбутнім фохівцям самостійно поповнювати професійні знання, досліджувати закордонну науковотехнічну літературу, пов'язану зі своїм фрахом, поповнювати свій словниковий запас технічною термінологією, дозволить ознайомлюватися із зарубіжним досвідом i з досягненнями сучасної науки і техніки в іншомовному середовищі, дасть можливість працевлаштуватися на високооплачувану працю.

Висвітлено основні сучасні освітні підходи щодо пошуку ефективної та досконалої методики викладання англійської мови за просресійним спрямуванням у технічних фрахових коледжах, які передбачатимуть поєднання навчання англійської мови за професійним спрямуванням із розвитком особистісних якостей студентів, ознайомлення із культурою країни, мова якої вивчається, набуття спеціальних навичок, що грунтуються на профессійних і лінгвістичних знаннях

Наголошено, що вільне володіння англійською мовою дасть змогу майбутньому фрахівцеві реалізувати всі цілі просресійної діяльності, ознайомлюватися з новими науковими дослідженнями, розробками, технологіями та процесами, дасть можливість повноцінно працювати із закордонними інсрормаційними джерелами, вільно встановлювати партнерські контакти із зарубіжними колегами у профессійній сфрері. Ключові слова: англійська мова за професійним спрямуванням, іноземна мова за профресійним спрямуванням, професійноспрямоване навчання, просресійна компетентність, професійне становлення студентів технічних спеціальностей.

The article deals with the peculiarities of the process of professionally-oriented English studying by students of engineering profession, the formation of their relevant professional knowledge and skills in the environment of foreign communication.

The nature of such concepts as "professionallyoriented foreign language", "professionallyoriented English", "professional orientation", "professional competence" is analyzed.

The main requirements of the present epoch to the professional formation of students of engineering profession, and securing the process of professionally-oriented English learning are revealed.

It is noted that the extending study of professionally-oriented English will help future specialists to widen independently their professional knowledge, research foreign scientific and technical literature connected with their profession, enrich their professional vocabulary, allow acquaint themselves with foreign experience and achievements of modern science and technology in the world, give a chance to find a highly-paid job.

The main modern educational approach to finding an effective and perfect methodology for teaching professionally-oriented English in technical professional colleges, which will provide a combination of mastering foreign language and the development of students personal characteristics, acquaintance with the culture of country, the language of which is studied, getting special skills based on professional and linguistic knowledge are found out. It is emphasized that perfect knowledge in English will help the future specialist to attain all his professional objects, study new researches, technologies and scientific processes, work with foreign scientific publications, fluently speak with foreign business partners and colleagues.

Key words: professionally-oriented English, professionally-oriented foreign language, professional-oriented study, professional competence, professional formation of students of engineering profession.
Постановка проблеми у загальному вигляді. За сучасних умов транссрормації в освітній сорері актуалізуються нові завдання і вимоги щодо формування професійної компетентності технічного спрямування у студентської молоді, а також якісного педагогічного забезпечення освітнього процесу, підготовки висококваліфікованого педа- гогічного персоналу, який би забезпечував рефрормування змісту компетентної підготовки кваліфрікованих спеціалістів до майбутньої трудової діяльності в Україні й у середовищі іншомовної комунікації. Саме у сучасному високорозвиненому суспільстві формування профресійної компетентності у технічних закладах освіти має бути 
всеохоплюючим, методично забезпеченим, систематизованим і інтегрованим компонентом всієї системи навчально-освітнього процесу. Тому проблема фрормування профресійної компетентності у студентів технічних спеціальностей машинобудівного і нафтогазового спрямування повинна першочергово вирішуватися й удосконалюватися технічними закладами освіти, які повинні готувати компетентного, відповідального, ініціативного, творчо думаючого, дисциплінованого фрахівця 3 глибокими знаннями іноземної мови за професійним спрямуванням, оскільки питання забезпечення сорери промисловості висококваліфрікованими, мобільними й інтелектуально розвинутими майбутніми працівниками з високою професійною культурою праці нині стає дедалі важливішим і актуальнішим.

у забезпеченні якісною вищою фраховою і передфаховою освітою, яка $є$ важливою у випереджаючому й інноваційному розвитку освіти, науки та техніки, провідну роль повинні відігравати технічні фрахові заклади освіти, зокрема технічні коледжі, які і будуть за правильної організації навчального освітнього процесу забезпечувати якнайкращі всеохоплюючі умови для всеосяжного розвитку, самоствердження і самореалізації особистості майбутніх фрахівців - бакалаврів, молодших спеціалістів і молодших фрахових бакалаврів. Саме тому необхідними вимогами до сучасного конкурентоздатного фахівця $€$ не лише поглиблені знання у кваліфікаційній професійній сфері своєї справи, але і можливість і вміння вирішувати професійні завдання у середовищі іншомовної комунікації. Тому в технічних коледжах останнім часом приділяється багато уваги поглибленому професійно спрямованому вивченню іноземної мови, зокрема англійської.

Аналіз останніх досліджень і публікацій. Дослідженню проблеми професійного становлення фрахівців завжди приділялася велика увага. Зокрема, науковці досліджували такі їі аспекти, як профресійна підготовка фахівців у вищій школі (А.М. Алексюк, В.І. Бондар, Н.М. Дем'яненко, В.І. Євдокимов, В.Г. Кузь, Л.І. Нічуговська, П.І. Образцов, О.О. Романовський, В.К. Сидоренко, М.І. Шкіль, О.Г. Ярошенко та ін.); питаннями політехнічної освіти та формуванням професійної культури праці займалися П.Р. Атутов, Б.І. Адаскін, С.Я. Батишев, С.Е. Матушкін, В.М. Мадзігон, Г.І. Ойзерман, В.А. Поляков, М.М. Скаткін, В.П. Струманський. Методику впровадження іншомовної комунікації у підготовці студентів і методику навчання іноземних мов у професійній комунікаційній сорері майбутніх фрахівців технічних спеціальностей висвітлено у наукових працях О. Бігич, Л. Голованчук, А. Маркової, О. Потебні, В. Скалкіна, Н. Скляренко, Л. Щерби. Також важливими працями з дослідження методів навчання англійської мови є праці авторів зарубіжжя: Д. Баддена, Дж. Белла, Дж. Скрівенера, К. Шанка.

Виділення не вирішених раніше частин загальної проблеми. Освітні європейські інтеграційні процеси, що є для нашої країни неминучими, необхідними, всеохоплюючими та перспективними, вимагають постійного переосмислення, оновлення й удосконалення нашої освітньої системи професійної підготовки студентів технічних спеціальностей як конкурентоспроможних спеціалістів на ринку праці, оскільки становлення фрахівців як професіоналів у своїй галузі із глибокими фраховими знаннями та знанням іноземної мови за професійним спрямуванням є важливим і затребуваним як у нашій країні, так і в середовищі іншомовної комунікації. Проблема підготовки майбутніх фрахівців, котрі би могли працювати в будьякому середовищі, зокрема середовищі іншомовної комунікації, залишається актуальною.

Мета статті. Незважаючи на численні дослідження проблематики з вивчення іноземної мови за прооресійним спрямуванням, окремі питання розв'язані лише частково. 3 огляду на це вважаємо актуальним на основі аналізу та пошуку шляхів удосконалення навчального процесу із забезпеченням поглибленого вивчення англійської мови за професійним спрямуванням виокремити завдання із забезпечення якісного профресійного становлення студентів технічних спеціальностей відповідними методами та засобами, що й стане метою нашого дослідження.

Виклад основного матеріалу. Розвиток ринкових відносин у сучасному світі характеризується вимогою впровадження в освітній процес освітніх технологій і новітніх напрямів забезпечення високої якості освіти та професійної підготовки майбутніх фрахівців технічного спрямування.

Основна роль у розвитку науково-технічного прогресу належить машинобудівній і нафтогазовій промисловості. Саме в цих галузях створюються, розвиваються і матеріалізуються новітні науковотехнічні задуми, ідеї, створюються нові засоби та методи праці, автоматизовані системи, автоматизовані процеси, машини, механізми, технології, що стають визначальними й у розвитку інших галузей народного господарства, фрормуються перспективи масштабного виходу на новітні ресурсозберігаючі та ресурсонезалежні технології, принципово нові галузеві процеси і системи задля збереження людського потенціалу, підвищення продуктивності праці, технології виробництва, забезпечення високої продуктивності та якості продукції. I саме з вимогами сучасності постає проблема оволодіння студентами технічних спеціальностей глибокими знаннями й уміннями, професійними компетентностями, креативними здібностями, перспективними ініціативами, внутрішніми потребами до безперервного розвитку і саморозвитку, 
комунікабельності в іншомовному середовищі та конкурентоспроможності на ринку праці [7, с. 197]. Роботодавці сьогодення потребують не лише компетентних і висококвалісрікованих у межах своєї професії фрахівців, але і мобільних, здатних вирішувати профресійні задачі нестандартними креативними рішеннями, спеціалістів із глибокими знаннями англійської мови за професійним спрямуванням. Саме від рівня підготовки фрахівця технічного спрямування, сорормованості його професійних характеристик значною мірою залежить успішне виконання соціального замовлення держави на фрахівця з високою професійною компетентністю.

Для нашої держави цей освітній процес став незворотнім і дуже важливим. Поглиблені та ґрунтовні знання студентів технічних спеціальностей, їхні власні ціннісні орієнтації та прагнення до освіти і самоосвіти значною мірою здобуваються під час професійно-орієнтованого навчання. Випускник технічного коледжу - це фрахівець, який здобув відповідну професійну підготовку, швидко орієнтується в нових сучасних ситуаціях, володіє однією чи кількома іноземними мовами за професійним спрямуванням, користується спеціальною технічною термінологією, у т. ч. вільно оперує професійно-технічною термінологією на англійській мові, самостійно розв'язує професійні задачі, швидко орієнтується у складних профеесійних завданнях, креативно та швидко вирішує їх. Саме знання іноземної мови за професійним спрямуванням і $€$ однією з основних вимог роботодавців до кваліфікаційних характеристик фрахівців технічного спрямування, які і стають визначальними під час працевлаштування. Це засвідчує, що є великий попит на фахівців технічних спеціальностей із відповідним профресійним рівнем і поглибленими знаннями з англійської мови за професійним спрямуванням.

Важливе значення в освітній системі технічних закладів освіти має вивчення саме загальнотехнічних і спеціальних профрілюючих дисциплін, які найкраще сприяють формуванню таких елементів профресійної компетентності, як вміння творчо і технічно мислити, раціонально використовувати сучасні новітні технології, а ще організовувати свою технічну творчість, планувати, проектувати, набувати вміння керувати виробничим процесом, творчо виявляти себе у ньому, оскільки висококваліфікована та грамотна людина $€$ не тільки однією з учасників процесу розвитку науки, техніки й виробництва, а й результатом всієї цієї системи [5, с. 147].

Відзначено, що на сучасному етапі розвитку суспільства у сорері освіти, науки та техніки постають важливі освітні завдання і проекти 3 фахової підготовки студентів технічних спеціальностей, вирішення яких уможливлювало б необ- хідність одночасного навчання профрілюючих технічних дисциплін разом із вивченням англійської мови за професійним спрямуванням. Оскільки англійська мова за професійним спрямуванням $€$ важливим компонентом у фрормуванні професійної компетентності майбутніх фрахівців, постає нагальна потреба приділити особливу увагу вивченню цієї дисципліни в технічних коледжах. Саме зараз назріла потреба удосконалювати систему пошуку шляхів інноваційної підготовки кваліфікованих фрахівців технічних спеціальностей, котрі б могли креативно і нестандартно мислити і працювати на перспективу в середовищі, що постійно і швидко змінюється, - ось це і $€$ головною метою забезпечення потреб України і світу в освічених висококваліфікованих фрахівцях [4, с. 322].

Сучасні інноваційні технології вимагають від випускників технічних закладів освіти не просто високої освіченості та кваліфрікованості, а й активності пошуку, відповідальності, самостійності, впевненості у власних силах, здатності до самоосвіти, вміння жити, творити і працювати в постійно змінному середовищі, бути соціально зорієнтованими.

Саме тому технічні коледж, які готують майбутніх фрахівців своєї справи, повинні брати активну участь у прискореному, випереджувальному, інноваційному розвитку освіти, науки і техніки, мають забезпечити найкращі умови для всебічного розвитку, самоствердження і самореалізації особистості майбутніх профресіоналів своєї справи. Насамперед технічним закладам освіти необхідно приділити значну увагу поглибленому вивченню англійської мови за професійним спрямуванням, бо володіння нею не тільки розширює світогляд студента але й підвищує його загальний інтелектуальний рівень, що і $є$ основним засобом для вирішення певних професійних завдань, важливою складовою частиною професійного становлення студентів як майбутніх фрахівців у своїй професійній сорері.

Згідно з останньою інфрормацією Німецького Інституту економічних досліджень у сучасній Європі кожен п'ятий фрахівець у своїй професійній діяльності користується знаннями іноземної мови. Знання іноземної мови нині є невід'ємною складовою частиною професійної компетентності фрахівця своєї справи 3 вищою технічною освітою, що допомагає йому у перспективному працевлаштуванні, відкриває кращі можливості у здобутті високооплачуваної та престижної роботи.

Проблеми поглибленого вивчення іноземної мови за професійним спрямуванням на відповідному рівні студентами технічних спеціальностей висвітлені у багатьох працях науковців минулого і сучасності, а також визначено зростаючою 
роль іноземної мови за професійним спрямуванням у професійному становленні студентів технічних спеціальностей [5, с. 30]. Як зазначено дослідниками, і ми погоджуємося, знання англійської мови за професійним спрямуванням дасть змогу студентам технічних коледжів під час проходження виробничих і технологічних практик у нашій країні та за кордоном самостійно поповнювати свої профресійні знання і вміння, ознайомлюватися з іншомовною науковою технічною літературою, 3 найновітнішими досягненнями науки і техніки, набувати закордонного досвіду у відповідній професії.

Навчання англійської мови за професійним спрямуванням повинно бути організоване так, щоб обов'язково враховувалися потреби студентів, а для цього повинно створюватися мотиваційне середовище, яке б мотивувало студентів до старанного і поглибленого вивчення англійської мови з орієнтацією на особливості майбутньої професії.

Важливу роль у вивченні англійської мови за професійним спрямуванням відіграють компетенції, які набуваються студентами саме під час навчання на другому і третьому курсах фрахових технічних коледжів, оскільки за період навчання у коледжі студенти повинні опанувати не тільки розмовну мову і лексику як її складову частину, але і навчитися використовувати здобуті знання для отримання необхідної інорормації в рамках своєї спеціальності. I тут же ставляться вимоги до вивчення англійської мови: навчання повинно бути послідовним і систематичним, йти від найпростішого до складного, має бути дотриманий високий рівень узагальненості.

Профресійно спрямоване і поглиблене вивчення англійської мови в технічних фрахових коледжах вимагає від учасників освітнього процесу відбору новітніх фрорм, методів і засобів навчання, розроблення і впровадження в навчально-виховний процес нових навчальних планів, нових робочих програм навчальних дисциплін, методичних розробок, вказівок, методичних матеріалів, дидактичного матеріалу, навчальних посібників і підручників та інших можливостей для інноваційного навчання [8, с. 52; 9, с. 97].

Досліджуючи специфіку профрільних навчальних технічних закладів і їхніх профрільних спеціальностей, необхідно обов'язково враховувати у розробленні методичних матеріалів основні напрями підготовки студентів технічних коледжів, організовувати навчання за певними напрямами і галузями: роботу над спеціальними технічними текстами, вивчення відповідних спеціальних тем і текстів для розвитку усного мовлення, вивчення лексичного мінімуму у відповідності із спеціальністю, вивчення певної, згідно з тематикою, технічної термінології, лексичного мінімуму за спеціальностю, вироблення комунікативної компетенції у сорері просресійної діяльності, створення спеціальних посібників для активізації граматичного та лексичного матеріалу, організацію самостійної роботи та ії методичне забезпечення спеціальною літературою, створення навчальних комплексів професійного спрямування відповідно до вимог сучасності, що є надзвичайно важливим за умов дистанційного навчання [5, с. 28].

Досліджуючи процес навчання іноземної мови як засіб фрормування професійних компетентностей майбутнього фахівця, Н. Гальскова вказує, що під час вивчення навчального матеріалу профрілюючих дисциплін разом із іноземною мовою створюються нерозривна двостороння взаємодія між бажаннями студента здобути професійні знання й успішним оволодінням англійською мовою за професійним спрямуванням. Науковець зазначила, що у зміст вивчення іноземної мови потрібно включати комплекс спеціальних професійних (мовних) вмінь, мовний матеріал (граматичний, лексичний, фронетичний, орфографрічний), комунікативну сореру, мовні дії та мовленнєвий матеріал, тематику текстів, а ще дослідити систему освіти і культурного простору країни, мова якої вивчається [2, с. 2-7].

Сучасний підхід до вирішення питань 3 розроблення і впровадження в навчальний освітній процес ефрективної та вдосконаленої методики 3 викладання і навчання англійської мови за професійним спрямуванням у технічних фрахових коледжах полягає у застосуванні як традиційних методик навчання, так і обов'язково інноваційних. Це дасть змогу студентам поглиблювати свої знання під час вивчення спеціальних технічних дисциплін. Цілеспрямоване застосування новітніх сучасних педагогічних технологій у процесі вивчення англійської мови за профресійним спрямуванням студентами технічних спеціальностей матиме позитивний вплив не лише на засвоєння знань і вмінь, але і на якісне профресійне становлення і самовдосконалення майбутніх фрахівців, а також дозволить їм успішно використовувати англійську мову у своїй майбутній професійній діяльності.

Обґрунтовуючи вище вказане та на основі власного досвіду вивчення і викладання англійської мови за професійним спрямуванням і викладання спеціальних дисциплін професійного спрямування, ми можемо навести приклад-фррагмент методичного забезпечення заняття, який містить навчальний матеріал англійською мовою за професійним спрямуванням, а саме технічний текст, комплекс лексичних вправ, спрямованих на опрацювання та засвоєння спеціальної технічної термінології й автоматизацію навичок вживання лексико-граматичних конструкцій.

Фрагмент заняття з англійської мови за профресійним спрямуванням [3]. 
Task 1: Read and translate the following article, copy out unknown words

Types of corrosion

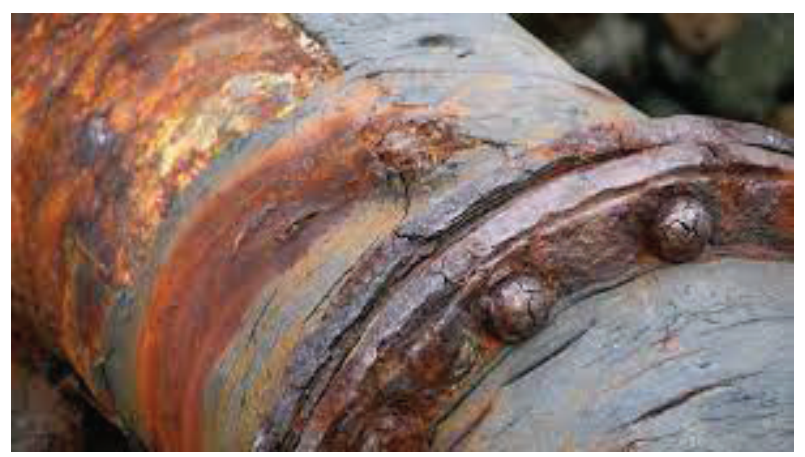

Corrosion is a process through which metals in manufactured states return to their natural oxidation states. This process is a reduction-oxidation reaction in which the metal is being oxidized by its surroundings, often the oxygen in air.

There are many different corrosion types which are defined by their chemical reaction, the environmental challenges and the chemical composition of the material. The most common kinds of corrosion are: general corrosion, galvanic corrosion, pitting corrosion, stress corrosion cracking.

General corrosion occurs when most or all of the atoms on the same metal surface are oxidized, damaging the entire surface. Most metals are easily oxidized: they tend to lose electrons to oxygen (and other substances) in the air or in water. As oxygen is reduced (gains electrons), it forms an oxide with the metal.

Pitting is one of the most destructive types of corrosion, as it can be hard to predict, detect and characterize. Pitting is a localized form of corrosion, in which either a local anodic point, or more commonly a cathodic point, forms a small corrosion cell with the surrounding normal surface. Once a pit has initiated, it grows into a "hole" or "cavity" that takes on one of a variety of different shapes. Pits typically penetrate from the surface downward in a vertical direction.

Stress corrosion cracking is a result of the combination of tensile stress and a corrosive environment, often at elevated temperatures. Stress corrosion may result from external stress such as actual tensile loads on the metal or expansion/ contraction due to rapid temperature changes. It may also result from residual stress imparted during the manufacturing process such as from cold forming, welding, machining, grinding, etc. In stress corrosion, the majority of the surface usually remains intact; however, fine cracks appear in the microstructure, making the corrosion hard to detect.

Galvanic corrosion is the degradation of one metal near a joint or juncture that occurs when two electrochemically dissimilar metals are in electrical contact in an electrolytic environment; for example, when copper is in contact with steel in a saltwater environment.

Task 2: Find in the text English equivalents for:

Структура, окислення, реакція, окислюватися, вся поверхня, електрохімічна корозія, виразкова (крапкова) корозія, зварювання, різнорідний метал, метод холодного профрілювання, механічна обробка різанням, шов, тріщина, механічна корозія, корозійне середовище.

Task 3: Answer the questions

1. What is corrosion?

2. Is corrosion a dangerous problem?

3. Name the most common kinds of corrosion.

4. What process is called galvanic corrosion?

5. In your opinion, what type of corrosion is the most destructive? Why do you think so?

Task 4: Make up the plan for analysis of the article

Висновки. Високий рівень оволодіння спеціальними технічними дисциплінами й одночасно поглиблене вивчення англійської мови за професійним спрямуванням і буде важливою характеристикою особистості, її професійним становленням як фрахівця своєї профресії, і ґрунтовною основою її готовності до майбутньої трудової діяльності. Потреба суспільства у висококвалісрікованих і високоосвічених фрахівцях своєї справи диктується вимогами науково-технічного прогресу, які визначають необхідний рівень підготовки студентської молоді до самостійного трудового життя. Тому від учасників освітнього процесу вимагається постійно вдосконалювати навчально-виховний процес, застосовувати нові інноваційні методики у викладанні, постійно розробляти й оновлювати методичне забезпечення, враховуючи специфіку вивчення технічних профрільних дисциплін і специфріку вивчення англійської мови за професійним спрямуванням, які будуть необхідні в майбутній професійній діяльності фрахівців.

\section{БІБЛІОГРАФІЧНИЙ СПИСОК:}

1. Зязюн І.А. Концептуальні засади теорії освіти в Україні. Педагогіка і психологія професійної освіти. 2000. № 1. С. 11-24.

2. Гальскова Н. Д. Современная методика обучения иностранному языку : пособие. Москва : АРКТИГлосса, 2000. 165 с.

3. Грицик Г.О. Англійська мова. Збірник вправ для студентів спеціальності «Обслуговування систем управління та автоматики». Дрогобич : видавничий центр ДМТК, 2018. 72 с.

4. Педагогіка вищої школи : навчальний посібник / 3.Н. Курлянд, Р.І. Хмелюк, А.В. Семенова та ін. ; за ред. З.Н. Курлянд. Київ : Знання, 2007. 495 с.

5. Ляховицкий М.В. О некоторых базисных категориях методики обучения иностранным язикам. Иностранные языки в школе. 1973. № 1. С. 27-34.
6. Мадзігон
B.M.
Організація
трудового навчання та виховання учнів 5-7 кла- 
сів / авт. кол. : Левченко Г.Є., Волощук І.С., Гнеденко О.П., Єременко Г.М., Кондратюк Г.А., Легкий М.П., Мазур В.Г., Моцак В.З., Полька Н.С., Пустовіт Н.О., Рманова С.М., Сингаївський Д.В., Тараненко В.Ю., Тименко М.П., Цесельський В.Л., Губченко А.О., Антонюк М.С. Київ : Преса України, 1992. $191 \mathrm{c}$.

7. Малик Л.Б. Культура праці студентів технічних коледжів як важлива складова навчальної та трудової діяльності майбутніх фрахівців. Проблеми сучас- ної педагогічної освіти. Сер. : Педагогіка і психологія. 2014. Вип. 43. Ч. 2. С. 195-203.

8. Образцов П.И., Ахулкова А.И., Черниченко О.Ф. Проектирование и конструирование профрессионально-ориентированной технологии обучения. Орел, 2005. 61 с.

9. Образцов П.И., Иванова О.Ю. Профессионально-ориентированное обучение иностранному языку на неязыковых фракультетах вузов. Орел : ОГУ, 2005. 114 c. 